\title{
INTERNATIONALIZATION OF CZECH COMPANIES IN BRAZIL
}

\author{
Renan Stefanutti \\ University of São Paulo (USP) \\ Engineering School of São Carlos (EESC), Industrial Engineering \\ Av. Trabalhador São Carlense, No. ${ }^{\circ} 400$, São Carlos, Brazil, Postal: 13566-590 \\ e-mail: renan.stefanutti@gmail.com
}

\begin{abstract}
The first part of this article brings a review of the Czech-Brazilian bilateral trade and its changes throughout the years, showing the most common exports and imports. In the second part we expose how to operate inside the largest market in Latin America, Brazilian barriers to trade and bureaucracy are scrutinized, showing examples and drawing comparison with the reality in Czech Republic and Germany. Besides that, some protective measures are analyzed in order to show the country's idea of protectionism and how this affects foreign goods nowadays. In its third part, the article analyzes the ways a company can properly deal inside the country, showing which businesses from different sectors are already profiting from the operations available by the law.
\end{abstract}

\section{Keywords}

Brazil; Czech Republic; Foreign trade; Bilateral relations; Laws; Taxes.

\section{Introduction}

Brazil is one of the most diverse and folkloric countries in the world, being known for its football and forests. However, the country has also many economical qualities, as its raw materials abundance, huge work force and a leading role in Mercosur [42].

Czech companies, on other hand, play an important part in the European scenario, supplying Germany and the UK with its industrial goods. However, over the past years it has been focusing on expanding the trade with non-European countries, in order to protect itself against bloc crisis [48].

The first part of this article focuses on the Czech-Brazilian relations and how they have evolved throughout the years, analyzing the amount and types of goods exchanged. In the second part, we observe the internal environment for business, showing several difficulties to operate in the country. In the third part, we overview the ways a company can expand its business to Brazil.

Following its colonial historical heritage, Brazilian trade relies on commodities export and manufactures import. Analyzing Brazilian imports in 2016 [43], 10\% are basic products, 4\% are semi-manufactured and $86 \%$ are manufactured ones, showing the country potential for new Czech companies to operate in.

To keep developing in the changing world we live in, Czech companies must adapt to new market needs and profit from them. Kuada [40] says that "although international business will still be centered on the interlinked economies of the Triade - Western Europe, Japan and North America -the contribution of other countries to the world trade ... will grow in significance". In addition, according to this scenario, Brazil is already playing a major role. 
Aiming to fulfill its objectives, the present study aims at supplying a lack of information about the Czech-Brazilian trade and ways to do business. We have tried to review more literature about the subject, however, none was found on this specific topic. Ellis [41] highlights that "Culture, language and currency are key issues on doing international business", all subjects that are going to be explored in the following text.

\section{$1 \quad$ Research Objectives}

This article has two objectives. The first one is to analyze the Czech-Brazilian bilateral trade relations. The second aim is to describe how to operate on the Brazilian market, identifying the country's barriers and ways to overcome them.

\section{$2 \quad$ Research Methods}

This is a problem-oriented research. The entire study has been constructed aiming to help the Czech companies to expand their business and to decide whether to keep exporting from the Czech Republic or to open a factory in Brazil. To do so, this article will analyze data from the World Bank, Brazilian Government and Czech Government. Also, we will use statistical data from several Brazilian institutes to measure the country internal barriers and desire to do business. The applied research methods are mainly comparative analysis, synthesis, and deduction.

\section{Czech - Brazil Trade and Bilateral Relations}

There are fifteen bilateral agreements between the Czech Republic and Brazil. However, as has already been observed, due to Mercosur, Brazil cannot negotiate tax reduction without the other member states. As a result, most of the treaties are oriented to cooperation and help, e.g. Treaty for diplomatic work (13/06/1997) [1].

The commerce between Brazil and Czech Republic has grown strong over the last 15 years. We can observe in Figure 1 that turnover is growing due to the volume of Czech exports to Brazil, although the volume of Czech imports is almost the same. For example, the total exported amount from the Czech Republic was 110 million USD in 2004, against 610 million in 2013. On the other hand, the Czech Republic imported 80 million USD in 2004 against 55 million in 2013.

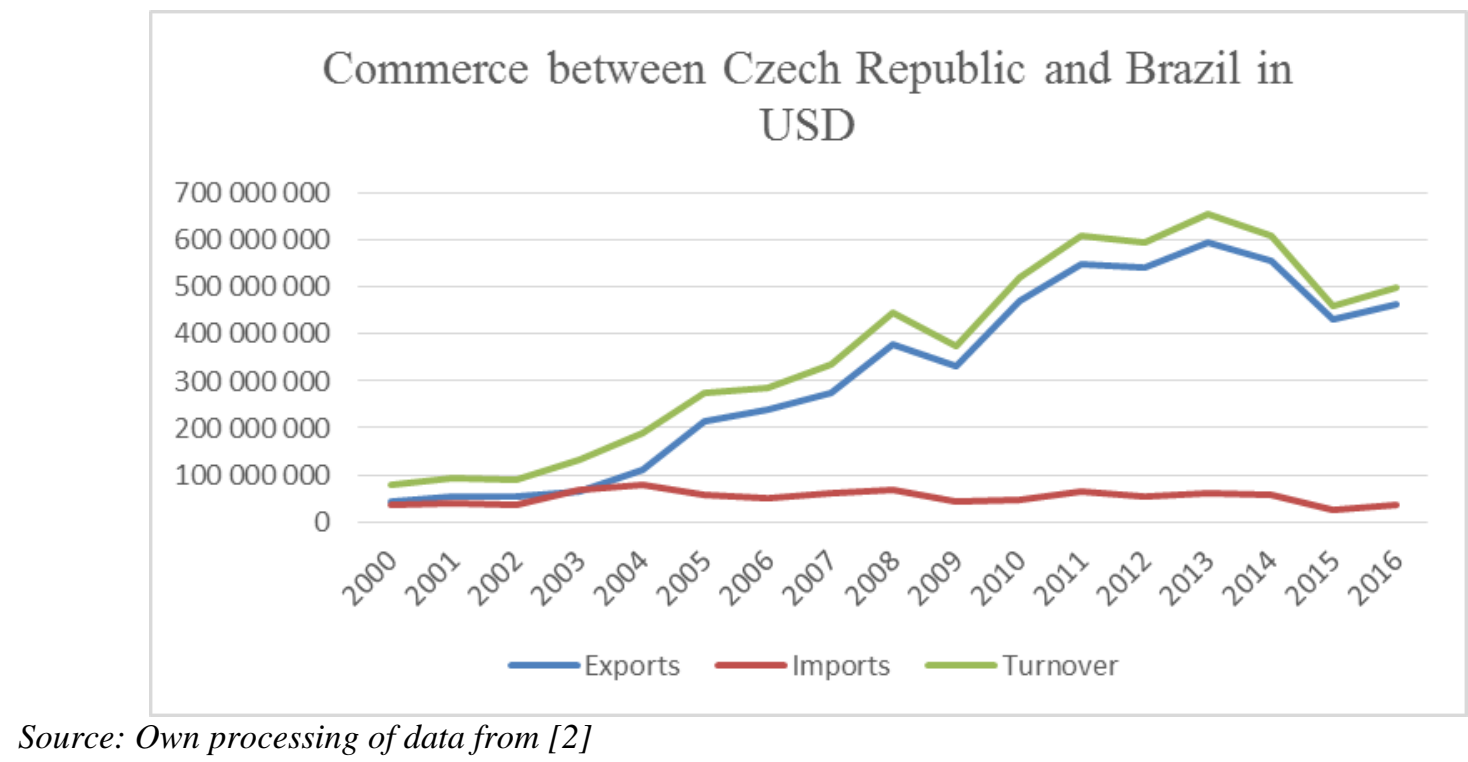

Fig. 1: Trade in goods between the Czech Republic and Brazil in USD (2000 - 2016) 
Analyzing the data, we can observe that the Czech exports are focused on manufactured items, with special attention to machines, transport equipment and its parts, which, together, correspond to $65 \%$ of all exports, as can be seen in Table 1 .

Tab. 1: Top Czech export trade categories to Brazil in USD according to the Harmonized System (2016)

\begin{tabular}{|l|r|r|}
\hline Product & Volume in USD & \% Total \\
\hline Total & $464,887,719$ & $100 \%$ \\
\hline Machines and parts (XVI) & $182,562,772$ & $39 \%$ \\
\hline Transport equipment and parts (XVII) & $120,301,256$ & $26 \%$ \\
\hline Plastic and rubber (VII) & $46,189,131$ & $10 \%$ \\
\hline Metals (XV) & $31,785,658$ & $7 \%$ \\
\hline Chemical products (VI) & $27,166,428$ & $6 \%$ \\
\hline Glass $(70) *$ & $7,815,154$ & $2 \%$ \\
\hline
\end{tabular}

* The Glass (subcategory) is in the table due to the expressive amount of sales and due to the importance that the material has to the Liberec region, place where this research was conducted.

Source: Own processing of data from [3]

It is also significant that since 2010 there has been an agreement on defense matters and, probably related to that, the first and the third most exported Czech products in 2016 in trade volume are related to military industry, as can be seen in Table 2.

Tab. 2: Top 5 Czech export products to Brazil in USD in 2016

\begin{tabular}{|l|c|r|r|}
\hline Product & $\begin{array}{c}\text { NCM } \\
\text { classification * }\end{array}$ & $\begin{array}{c}\text { Volume in } \\
\text { USD }\end{array}$ & \% Total \\
\hline Total & & $464,887,719$ & $100.00 \%$ \\
\hline Airplanes, Helicopters and parts & 88033000 & $49,198,183$ & $10.58 \%$ \\
\hline Combined products with sound reproducer & 85272100 & $28,461,004$ & $6.12 \%$ \\
\hline Armored vehicles & 87100000 & $18,005,125$ & $3.87 \%$ \\
\hline Catalyst in beehive & 38151210 & $17,572,704$ & $3.78 \%$ \\
\hline Chassis parts & 87082999 & $13,727,166$ & $2.95 \%$ \\
\hline
\end{tabular}

* NCM stands for the Mercosur classification system

Source: Own processing of data from [4]

Besides the exports for the army, we can see a lot of industrial production going to Brazil. It is important to observe Brazilian automotive needs and the fact that more than $9 \%$ of all Czech exports are related to this industry. From the total data, we observe that Czech exports growth is related to manufactured products, which are good for the Czech Republic economy. On other hand, Brazil keeps its tradition as a third world country, exporting raw materials and receiving industrialized products. From the historical data it can be presumed that this behavior will continue for a long time and the products showed in the TOP 5 will remain in the trade core.

\section{Brazilian Environment for Companies}

As it has already been mentioned, Brazil is a huge market with good connections within the majority of South American countries. As a result, some Czech companies are already operating in the country, with special attention to SEKO, in a partnership with Siemens in the production of aircraft engines. In addition, Centroprojekt is a construction company that experienced the big boom into Brazilian economy and now is facing a hard time [45].

However, in order to operate inside Brazil, there are a few issues to be aware of, as corruption, the amount of taxes, bureaucracy and trading barriers. For better understanding the 
business environment Table 3 highlights the ranking differences between doing business inside Brazil, the Czech Republic and Germany. In fact, Germany entered this comparison to give a more familiar point of view to an ordinary European person that might read this article. The original World Bank ranking compares 190 countries.

Tab. 3: Economy rankings for business

\begin{tabular}{|l|r|r|r|}
\hline & Brazil & Czech Republic & Germany \\
\hline Overall & 123 & 27 & 17 \\
\hline Starting a business & 175 & 81 & 114 \\
\hline Dealing with construction permits & 172 & 130 & 12 \\
\hline Getting Electricity & 47 & 13 & 5 \\
\hline Registering Property & 128 & 31 & 79 \\
\hline Getting Credit & 101 & 32 & 32 \\
\hline Protecting Minority Investors & 32 & 53 & 53 \\
\hline Paying Taxes & 181 & 53 & 48 \\
\hline Trading Across Borders & 149 & 1 & 38 \\
\hline Enforcing Contracts & 37 & 68 & 17 \\
\hline Resolving Insolvency & 67 & 26 & 3 \\
\hline
\end{tabular}

Source: Own processing of data from [5, 6, 7]

The World Bank ranking shows that Brazil is a difficult place to do business, being on the $175^{\text {th }}$ place when it comes to "Starting a business" and on the $181^{\text {th }}$ place concerning "Paying taxes". On the other hand, the Czech Republic with its strong trade policy is number 1 in "Trading across Borders" and Germany is the $5^{\text {th }}$ in "Getting Electricity". On the overall, Brazil comes in $123^{\text {rd }}$, the Czech Republic $27^{\text {th }}$ and Germany $17^{\text {th }}$. From the eleven topics analyzed by the institution, Brazil figures below the 100 better in seven of them, appearing on the TOP 20 worst countries three times.

Therefore, when analyzing the data in more detail, it is obvious that Brazilian economy needs urgent transformation by simplifying its bureaucracy and taxes, allowing the companies to perform in an easier way inside the country. In order to explore more about Brazilian obstacles to do business, in the next section it will be clarified and demonstrated how the country is developing right now.

\subsection{Bureaucracy - Laws}

Brazil faces a high level of bureaucracy. First, it is important to understand that there are the Federal, the State and the Municipal Governments, each with different laws and independent processes. For example, if you want to set up a factory in Brazil, one of the Federal Government agencies (Federal Receipt, IBAMA, INMETRO) will provide you a license to import. The State Government will charge you the ICMS (Tax over services and goods movement) and the Municipal Government is the one authorizing your factory to be installed in the city itself. Therefore, independently of the business, you are going to deal with several different authorities and agencies.

Focusing on the European Commission again, Brazil has been requested to reduce the bureaucracy, citing as an example a process for an engineer to be allowed working legally in the country and the non-adoption of the International Standards; the fact of the matter being that Brazil has its own agency for patterns, which differs to the ones used throughout the world. All these national specificities are seen as protective measures against free trade by WTO [8]. 
Another important data is the fact that from the 513 Brazilian congressional representatives, only 43 are lawyers. In other words, more than $90 \%$ of the people responsible for making the laws in Brazil have no degree or education on the matter. Therefore, we conclude that this is one reason why Brazilian bureaucracy is so confusing, large and non-efficient [9].

\subsection{Bureaucracy - Taxes}

In Europe, any time a purchase is made, there is a note going with the receipt stating the taxes, known as VAT, making it clear how much the customer is paying to the state. In Brazil, however, transparency is not so common in public offices, since there is no unified tax like the VAT. We believe that this is a measure to avoid public pressure for tax reduction. In Table 4 it is possible to observe the most representative taxes on consume in Brazil.

Tab. 4: Taxes on consume in Brazil

\begin{tabular}{|l|l|l|c|}
\hline Name & Description & To Whom? & How much? \\
\hline PIS / Confins & Social contribution $*$ & Federal & $0.62 \%$ to $7.6 \%$ \\
\hline ICMS & Tax on services and goods movement & State & $7 \%$ to $19 \%$ \\
\hline IPI & Tax on industrialized products & Federal & $0 \%$ to $55 \%$ \\
\hline ISS & Tax on services & Municipal $* *$ & $2 \%$ to $5 \%$ \\
\hline IOF & Tax on financial operations & Federal & $0.38 \%$ to $25 \% * * *$ \\
\hline
\end{tabular}

* Contribution to Social Programs and Social Security. In Brazil, Social Security is financed by income taxes and by consume.

** Municipal but controlled by the federal government.

*** Operations to send money abroad [37].

Source: [10]

One of the main aspects in Table 4 is the Column "To Whom", in which we can see that the taxes are paid to different entities. As a result, Brazil has more than 490,000 accountancy professionals who only deal with state bureaucracy. In addition, Brazil charges a $15 \%$ tax on the company final profit. The World Bank rates Brazil on the 181th position of places to pay taxes, putting the country into the top 10 more complex places in the world [5].

The two most expensive taxes are normally the IPI and the ICMS. The IPI is calculated product by product and the final amount over the good can be found in a table with 425 pages available on the Federal Agency website [11]. The ICMS, on other hand, is charged state by state, being equal to all products.

The standard VAT in the Czech Republic is $21 \%$ and in Germany it is $19 \%$. In Brazil, it is difficult to calculate an average VAT (see Sum of all taxes in Table 4) for all the products. Therefore, to highlight some goods, the total tax on beer is $55.60 \%$, on fuel $56.09 \%$, on airplane tickets $22.32 \%$ and on a car it is $35.27 \%$. As a result, more than $60 \%$ of the federal money covers these taxes and not income, as it is normal in developed countries [10].

Besides that, there are taxes on importation, compiled together with all Mercosur countries. These taxes are analyzed in Section 5. However, there is a list for exception products, giving Brazil the autonomy to change the amount charged on these products. The European Union has processed 11360 complains exactly about how Brazil uses this power to protect its industry, as we have already seen above.

\subsection{Syndicates + Labor Laws}

The work laws in Brazil are among the priority concerns to executives [13], with several strict regulations. For example, if the employer is going to dismiss someone, they need to keep this employee for one month after warning him about the cut or they have to pay a one-month salary in advance. Another important fact is the benefits, as transportation and meals, which 
the employer is obliged to pay. Putting all the salary taxes and benefits together, it is normal for this amount to represent more than $90 \%$ of the employee salary itself [14].

Tab. 5: Work benefits

\begin{tabular}{|l|l|}
\hline Benefit & What the law states \\
\hline Working hours & 44 hours \\
\hline Holidays & 30 running days (weekends included) \\
\hline Notice periods & 1 month \\
\hline Probation & 3 months \\
\hline Transport & The company must pay for the employee transport to work and back home \\
\hline Extra Hours & At least $150 \%$ the normal hour wage \\
\hline
\end{tabular}

Source: Author's own work based on [15]

From Table 5 we can observe the labor laws in Brazil. The Working hours, though 44 hours, are normally split between 5 days of 8 hours plus 4 hours on Saturdays. Unlike in Europe, holidays must be taken in succession and without interruptions. Therefore, nothing like "a long weekend" including Friday as a day off is possible.

Another problem is the frequency of former employees suing their companies asking for money compensating some kind of distress originated there [34]. In fact, in 2016 there were approximately 3 million new employment discrimination lawsuits. As an example of how this can escalate, there was a process against Volkswagen where some employees were prosecuting the company because they had to do their own laundry [16].

Another barrier is the syndicates, which, in some categories as the automotive, are very strong and frequently organize strikes with certain. For example, Hyundai factory in Piracicaba was on strike only 4 days after the inauguration. To understand the situation better, the Brazilian Employment Law (CLT) states that all employees are obliged to pay the syndicate of their category. Hence, the country has more than 15.000 very well organized syndicates that impose their wills over the workers, promoting strikes and negotiating salaries [17]. Another interesting fact is that there are no limits for the number of syndicates, so, for example, teachers in public schools have three huge ones. However, those syndicates have different agendas which means that sometimes one is pushing a strike and the others are not.

From all the obtained data we concluded that the amount and inefficiency of labor laws is one of the main reasons why the illegal work is accounting for almost 10 million people [12], against 95 million legal employees. According to recent available data, 50.9\% of Brazil population were economically active in 2013 [44]. This 2013 data is the freshest we could find.

\subsection{Corruption}

Brazil faces a huge amount of corruption. In fact, corruption is spread in all levels of governmental control, not being unusual to hear about small bribes paid mainly to regulatory organs. According to Transparency International [18], Brazil is the 79th country in this matter, on the same level as China and India, and 4 places below Tunisia.

It is important to bear in mind that Brazil was a Portuguese exploitation colony from 1500 to 1808, the year of the Royal family's arrival to Brazil. The objective has never been to develop the country itself, with no education and proper infrastructure available. As a result, since that time corruption has been a major issue. It is also important to understand that corruption is not only briberies, but also common "influence traffic", meaning that someone with public power (financial, juridical or political) pressures people to gain favors or advanced information to themselves or someone they favor [19]. 
Nowadays the "Car Wash" operation is running in Brazil, arresting businessmen and politicians for enormous schemes involving the World Cup, the Olympic Games and running the Presidential election of 2010/2014. In numbers, BBC [20] says that $2.5 \%$ of the Brazilian GDP went down in 2015 due to the operations side effects, as frozen contracts and penalties applied to the companies involved.

This operation became a symbol of justice in the country. Because of it, more than two hundred people were arrested, including two former governors from Rio de Janeiro state. This operation hit president Dilma's party, undermining her already weak position in the Congress and giving strength to the impeachment process, which took her out of the power in favor of the Vice-President [46].

\subsection{Financial Resources}

Finding financial resources is difficult in Brazil. As the interest rate commands how much the governmental titles are going to pay, Brazilian Central Bank has a high interest rate of $13 \%$ [21]. However, as we know, this makes the cost of borrowing money inside the country very expensive. For example, in the U.S.A. the interest rate is 1\% [22]. This also reflects the confidence the market has in the U.S.A. and explains its ability to pay its duties. On the other hand, Brazilian government does not share the same appreciation as the U.S.A., needing this high interest rate to keep the resources coming to the government.

As a result, many companies borrow money in the international market, with payments fixed in dollars which can represent a problem if the Real (Brazilian currency) devaluates a lot in a short period, letting the company with an unpayable debt. It is also important to observe that Brazil has a tax on money transactions (IOF) of $6 \%$ when it is related to foreign currency. The World Bank [5] rates Brazil on the 101th position to get credit.

All operations in Brazil are done in the national currency. However, the government allows some institutions to trade external currency as well, buying and selling them to the public for profit. It is possible to borrow money outside the country and exchange it to Reals. Nowadays, the government is pushing down the IOF for companies who borrow abroad, in order to bring dollars back into the economy [47]. In order to do so, a company only needs to contact an authorized agent (bank, currency houses), fill in the required forms and send the money from abroad to this agent.

\subsection{Language Barrier}

Unlike the current situation in Europe, where the number of foreigners is high, Brazil is a country with low levels of non-natives, having a history of immigrants that arrived in the country more than 100 years ago. Nowadays, neither the immigrants' original languages are spoken, nor is English. In fact, a research [23] shows that only 5\% of the population in Brazil can speak English. We conclude that this is related to a low level of education in the country, which affects other business aspects as well.

Therefore, almost entire official and non-official communication, laws, proceedings etc. are in Portuguese only. For example, from a quick research we can observe that the Sao Paulo state website $^{1}$ and the Brazilian Bank website ${ }^{2}$ (the largest governmental bank) are available only in Portuguese. It is even worse when observing the Inmetro ${ }^{3}$ and the Customs Agency ${ }^{4}$

\footnotetext{
${ }^{1}$ http://www.saopaulo.sp.gov.br

2 http://www.bb.com.br

${ }^{3}$ http://www.inmetro.gov.br

${ }^{4}$ http://idg.receita.fazenda.gov.br
} 
websites, where the English version, though available, is not actualized and does not provide the information needed to foreign people to operate in the country.

Therefore, in conclusion, it is very hard to find any worthwhile information in English, being practically mandatory to rely on Portuguese language speakers for the majority of the data that is going to be needed to establish a company inside the country. However, despite all troubles, it is possible to operate and profit in Brazil, as several multinational companies do by hiring local people to work for them.

\section{$5 \quad$ Possibilities to Operate in Brazil}

In order to increase the Czech trade with Brazil, this article will now show three most common strategies used by companies to operate inside the country, explaining the differences of opportunities and giving examples of enterprises that are operating there. Among these strategies belong national production, importation and producing in Paraguay.

\subsection{National Production}

Setting up a factory is a usual way to produce goods in Brazil and enjoy the market freedom all over Mercosur. The positive points are the low land cost, cheap workforce and proximity of raw materials suppliers. However, as already explained, there are a few barriers to have in mind, especially the legal requirements and syndicates that will require a lot of effort from the company. In addition, we in 4 we have already discussed some of the taxes that the company will be obliged to pay.

In general, the process to set up a company will consist of the operations summarized in Table 6.

Tab. 6: Opening a company in Brazil

\begin{tabular}{|l|l|l|}
\hline Procedure & Time & Costs \\
\hline Check Company name with Jucesp * & 1 day & No charge \\
\hline Pay registration fees & 7 days & $\mathrm{R} \$ 150.36$ registration \\
\hline Register at Jucesp * & 1 day & $\mathrm{R} \$ 110.8$ (expediting fee) \\
\hline $\begin{array}{l}\text { Register with the municipal } \\
\text { taxpayers }\end{array}$ & 1 day & No charge \\
\hline $\begin{array}{l}\text { Apply and obtain digital certification } \\
\text { for the e-invoice }\end{array}$ & 2 days & $\begin{array}{l}\text { The cost may vary from R } \$ 450.00 \text { to } \\
\mathrm{R} \$ 600.00\end{array}$ \\
\hline $\begin{array}{l}\text { Apply to the municipality for an } \\
\text { operations permit }\end{array}$ & $\begin{array}{l}90 \\
\text { days }\end{array}$ & No charge \\
\hline $\begin{array}{l}\text { Register and pay TFE (Registry Tax) } \\
\text { to the Municipal Taxpayers' } \\
\text { Registry }\end{array}$ & 1 day & $\begin{array}{l}\mathrm{R} \$ 425.46 \text { (for retailing business), may } \\
\text { vary in accordance with the company's } \\
\text { activities }\end{array}$ \\
\hline $\begin{array}{l}\text { Register the employees in the social } \\
\text { integration program (PIS) }\end{array}$ & 1 day & No charge \\
\hline $\begin{array}{l}\text { Open a special fund for } \\
\text { unemployment (FGTS) in bank }\end{array}$ & 1 day & No charge \\
\hline Notify the Ministry of Labor & 1 day & No charge \\
\hline $\begin{array}{l}\text { Registration with the Patronal Union } \\
\text { and with the Employees Union }\end{array}$ & 5 days & No charge \\
\hline $\begin{array}{l}\text { * State organ } \\
\text { Source: Author's own work based on [5] }\end{array}$ & \\
\hline
\end{tabular}


As it can be observed, the amount of bureaucracy is enormous and the cost of opening a company will be around 1300 Reals. The most time consuming process is to wait for a legal license from the municipality, which can extend up to 3 months. Together with all other proceedings, to open a company will probably take more than 100 days.

As an example of an international industry that went to Brazil, Faber Castell has a huge factory in São Carlos, responsible for $40 \%$ of the company global trade, supplied almost exclusively by local industries and Brazilian raw materials [24]. However, due to the increase of technology and complexity, most goods need several items from abroad to be concluded. In this case, one option is to set up the factory in the country and enjoy the "Nationalization" process.

To be a national product and pay fewer taxes, Brazilian government has an original law that demands $60 \%$ of the product value to be added inside the country. So, one alternative to import the needed parts and still pay less for the final product is importing semi-finished products and adding value to them, until the mandatory percentage is reached. As an example, automotive companies add value to wired systems by putting tape on it. In addition, the main example is the automotive assembly lines, which receive parts from all over the world and form a national product in the end.

The account made by the government is the one shown in Formula (1), where $I V$ is the value index, $X$ is the imported value and $Y$ is the final sale price. If $I V$ is more than $60 \%$, the product is considered national [25].

$$
I V=\left[1-\left(\frac{X}{Y}\right)\right] * 100
$$

\subsection{Importation}

Another option is to import finished goods. Though common, as can be seen by the amount of Chinese manufactured products sold inside the country [3], Brazil has some protectionist measures that tend to overtax finished goods, particularly if they are competing with the national industries. One good example is the car industry, for which it is very expensive to import finished cars; it is even illegal to import used ones [38]. Due to these taxes, Geely company closed its operations in 2016 for not being able to compete in the internal market [27]. In conclusion, the more industrialized the product, the heavier the taxes on it.

To import to the country, it is important to follow all the extensive legislation and requirements. The average procedure to import is shown in Table 7. 
Tab. 7: Importation process

\begin{tabular}{|c|c|}
\hline Step & Explanation \\
\hline Company & $\begin{array}{l}\text { First of all the company that is importing the products must exist in Brazil. } \\
\text { If it not so, the company must be opened as a juridical person. }\end{array}$ \\
\hline Siscomex & $\begin{array}{l}\text { The company must register itself into the External Trading System } \\
\text { (Siscomex). This system is going to be used to follow up all the legal } \\
\text { operations. Into the website (system), the company must choose the option } \\
\text { that best suit it and nominate an official representative. It is very common } \\
\text { for both small and large enterprises to nominate a Forwarding Agent, who } \\
\text { is a government-authorized person or a company that only deals with } \\
\text { official bureaucracy. }\end{array}$ \\
\hline Radar & $\begin{array}{l}\text { The Company needs to habilitate the Siscomex account into the nearest } \\
\text { federal office, which will insert it in the Radar (Federal Centralized } \\
\text { Network) system. }\end{array}$ \\
\hline $\begin{array}{l}\text { Legal } \\
\text { Requirements }\end{array}$ & $\begin{array}{l}\text { It is important to verify if the product has some restrictive measure against } \\
\text { it. Most products are free to enter the country. However, the government } \\
\text { keeps a list of products that must have a special license, called LI, to enter. } \\
\text { It is the case of cheese and glasses, for instance [28]. }\end{array}$ \\
\hline $\mathrm{NCM}$ & $\begin{array}{l}\text { Verify NCM (Mercosur tax table in accordance to the TEC - Common } \\
\text { External Tariff) to calculate the amount of taxes that are going to be paid } \\
\text { for the country. It is also important to see if the product is not on the } \\
\text { Brazilian exception list for the NCM, which means that the country can } \\
\text { target some categories of products with higher tributes to protect its } \\
\text { industries. This is, for example, the case of automotive companies. }\end{array}$ \\
\hline Tributes & $\begin{array}{l}\text { The company must pay all legal taxes to the government, based on the } \\
\text { NCM, through the creation of a DARF (Declaration of fiscal collection) to } \\
\text { be paid in a bank. }\end{array}$ \\
\hline DI & $\begin{array}{l}\text { After all the procedures mentioned above, including the LI, the system will } \\
\text { generate an Import Declaration. The importer company must present the DI } \\
\text { in the nearest Federal Agency with proof of tributes payments (DARF), } \\
\text { invoices and any other legally required documents. }\end{array}$ \\
\hline $\begin{array}{l}\text { Payment to the } \\
\text { company }\end{array}$ & $\begin{array}{l}\text { The payment must pass through the central Brazilian bank, converting the } \\
\text { amount from Reals to the proper currency (normally USD). }\end{array}$ \\
\hline Shipment & The products must be sent to Brazil. \\
\hline Documents & $\begin{array}{l}\text { The exporter company must send the Invoice, the Packing list (showing } \\
\text { what was shipped) and Proof of shipment to the importer company. }\end{array}$ \\
\hline $\begin{array}{l}\text { Desembaraço } \\
\text { Aduaneiro }\end{array}$ & $\begin{array}{l}\text { This process means that the legal representative must present all the needed } \\
\text { documents (section } 10 \text { and 4) and the tax payment proof. This information } \\
\text { will enter the system (SISCOMEX) and, when the Federal agency } \\
\text { authorizes it, the company will receive the C.I. (Proof of Import) and the } \\
\text { product is free to be commercialized in the country. }\end{array}$ \\
\hline
\end{tabular}

Source: Authors own work based on [35] and [28]

As can be observed, the process to import is extensive and involves many regulatory organs, with different agendas and operations. We highlight the "Legal Requirements" procedure, which, varying from product to product, can involve several institutions and laws, with the importer company being responsible for arranging all the required papers.

To better understand how a process like this involve taxes, UOL [26] made a simulation with a Mustang (car) being imported from the USA. In the end, as it can be seen, the cost of import can double the amount to be paid for the product. Especially in the automotive industry, this 
can be understood as the result of years of Lobby from the massive automotive companies in the country.

Tab. 8: Import taxes

Source: Authors own work based on [26]

\begin{tabular}{|l|l|}
\hline Tax & Value \\
\hline IPI & $40 \%$ \\
\hline Import Tax & $35 \%$ \\
\hline Cofins & $9,6 \%$ \\
\hline PIS/PASEP & $2 \%$ \\
\hline ICMS (for São Paulo) & $18 \%$ \\
\hline Marine Tax & $25 \%$ of the freight \\
\hline Forwarding Agent & $\mathrm{R} \$ 5.000$ \\
\hline Port Storage & $\mathrm{R} \$ 5.000$ \\
\hline International Shipment & $\mathrm{R} \$ 4.500$ \\
\hline
\end{tabular}

As shown in Table 8, the price will be more than double to reach the country legally. In addition, it is important to observe that the internal procedures are not clear enough since the Federal Customs Agency has the power to delay the products asking for extra explanation and can fine the products if they find something that is not in accordance with their rules.

\subsection{Trading EU - Paraguay - Brazil}

Recovering from a long past heritage, Paraguay is trying to develop again, bringing foreign industries to work in the country, mainly focusing on exports to Brazil. As it can be seen in Figure 2, Paraguay reached more than 700 million USD from Foreign Investment in 2013. For comparison, Paraguay trade turnover was only 19.6 billion USD in 2014 [29].

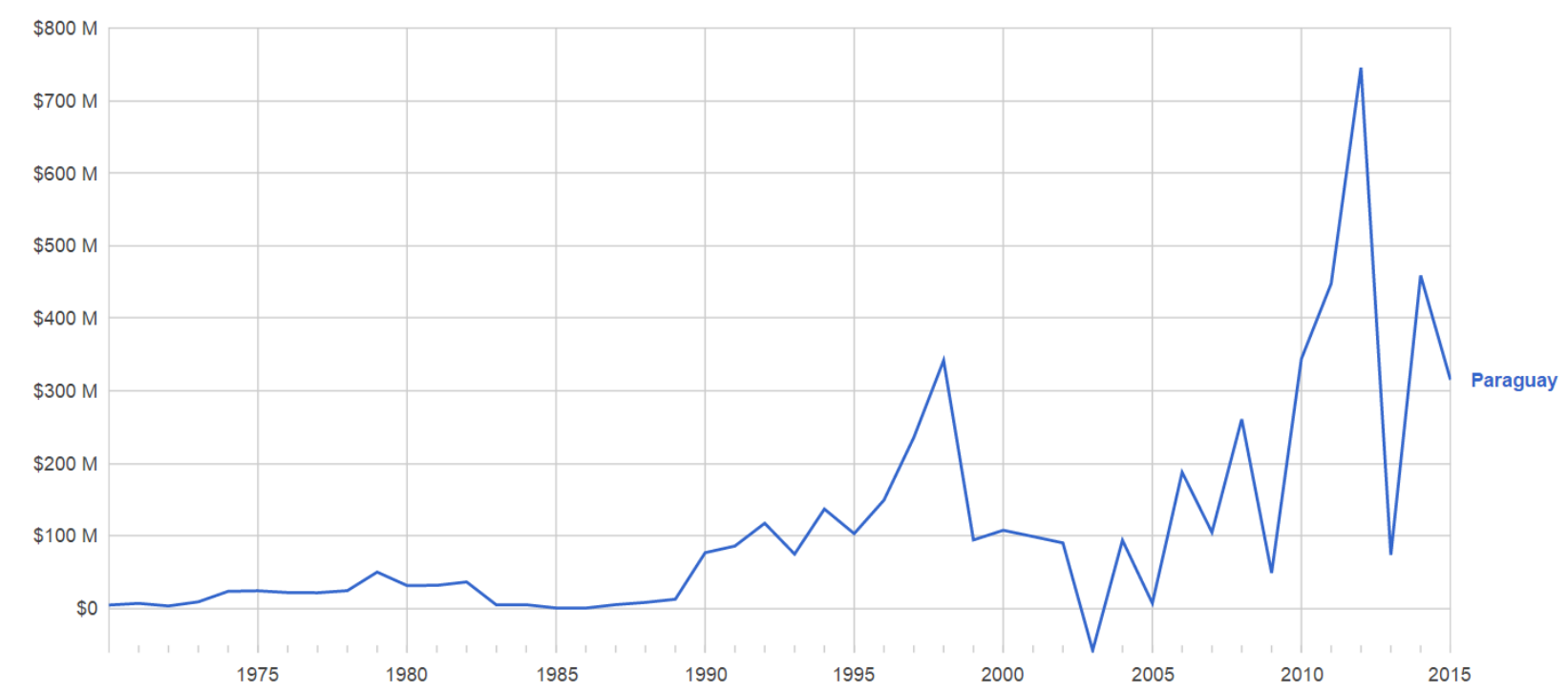

Source: Author's own processing of World Bank data through Google

Fig. 2: Paraguay FDI in USD (1970 - 2015)

In Figure 2 we can see the change that the Manquilla Law brought to the economy after 1996, with a huge increase of FDI. However, a few years later $(2003$ - 2008) as Brazil was booming, Paraguay was not attractive for the companies anymore. The situation was reverted after 2008 again.

Nowadays, the Manquila Law is generating a movement of Brazilian companies to Paraguay, due to the Crisis that is hardening the competition and the need for cutting down costs. The 
law imposes $0 \%$ taxes on machine and material import and there is a single tax of $1 \%$ on the aggregated price for sale, very similar to the standard European VAT [30].

By definition, the aggregate price is the sum of hired services, salaries and acquired goods used on the manufacture process. In addition, the company needs to have a temporary contract for importation and exportation to another company in another country. The company needs to employ Paraguayan people and to train them. Other advantage is the possibility for machinery importation without paying any taxes. However, if the machine is bought in Paraguay, they are going to add this cost into the $1 \%$. The law applies the tax exoneration to all other existing taxes and that can be created in the near future [31].

To be fitting, the company has to export $100 \%$ of its production. It can trade in the internal market up to $10 \%$ of the previous year production, but it still has to pay all the taxes that have not been applied. Those products also have to follow the same quality rules as the products that are being exported.

Another important factor is that it is cheaper to operate in Paraguay than in Brazil, with lower energy costs of 6.2 Cents $/ \mathrm{kWh}$ against 16.9 cents $/ \mathrm{kWh}$ in Brazil, according to the World Bank [32]. Also according to them Paraguay is on the 106th place of the best countries to do business, 17 positions ahead of Brazil.

As a part of Mercosur, the Paraguayan products can be traded in all the other countries without import taxes, except for the items that are on the countries' exclusion list. The most important feature of the Mercosur trade aspect is the original law, which demands $60 \%$ of the products to be made inside Mercosur countries and 40\% inside Paraguay itself [33], being a great opportunity to increase profit.

\section{Conclusion}

The Brazilian-Czech trade is important for both countries to keep developing independently in the world. As both economies are integrated in huge economical blocs, we need to understand the specific needs of trade and work on them, improving the quantity and the quality of the goods exchanged.

In the first part of this article we focused on the contemporary Brazilian trade structure, having shown that $43 \%$ of Brazilian exports are raw materials and $86 \%$ of the imports are manufactured products. Therefore, we observed that the colonial trading system is still operating, with Mercosur buying manufactured goods and selling raw materials.

Keeping the trade connection, we analyzed how the Czech Republic trades with Brazil. In addition, we observed how protective Brazil is with its own market and how the EU tries to change that through complains in the WTO. Focusing on the Czech Republic - Brazil trade, we observed that during the past 15 years the Czech imports have kept stable and concentrated on products to supply its industries, highlighting tobacco and automotive parts. On the other hand, Czech exports increased 6 times, reaching its historical peak of 600 million USD in 2013 against less than 100 million USD in imports, with a positive balance of more than 500 million USD.

In the second part, in order to enforce the Czech sales and expansion into the Brazilian market, we developed a study on how the market works and what the threats of negotiation are, exposing corruption, bureaucracy, the language barrier, syndicates, taxes and others. We also concentrated efforts on how to enter the market itself, showing step-by-step how to import to Brazil as well as the advantages of setting up a company there. 
We observed how a company can "nationalize" a product by adding value inside the country. We also reviewed an opportunity in Paraguay, which is growing fast due to the companies that are operating there and profiting from the Mercosur free trade deal, having a special law of $1 \%$ tax on the aggregated value for exportation. Therefore, we can conclude that, despite all the difficulties described in this article, it is possible to operate and sell products inside the country.

From all this we conclude that Brazil has a large market, especially when considering Mercosur as a whole, and a lot of companies are already profiting from this opportunity. Another opinion is that, due to the massive amount of bureaucracy and money needed to face it, Brazilian market gives an advantage to large companies, which can pay for the best attorneys, forwarding agents, accountancy personnel and advisors in order to get the best deals available. On the other hand, small and medium companies face several difficulties to contend with an unwieldy bureaucracy.

Having in mind the Czech industrial branches and comparing the different ways to operate in Brazil, we can conclude that, to protect its market share and expand its business, the Czech companies that sell assembled goods (high importation tax), as armored vehicles or airplane engines, should open factories in Brazil or in Paraguay instead of only exporting. This way, the companies will act like the large automotive manufactures and will have a stronger position in the country, protecting their interests against other enterprises and profiting from the tax reduction. To give an example already explained in this article, a car assembled inside the country will pay $35.27 \%$ of taxes, against more than $100 \%$ (in some cases) for an imported one. As other Czech branches are concerned, unless the importation tax (regulated by Mercosur) is enormous, we think they should stay in the Czech Republic and enjoy the political stability to grow and reduce costs at home.

Another clear conclusion is that, if the laws in Brazil were simpler and clear, with more market freedom, the country would be better integrated in the world economy and would profit from it, with more entrepreneurship. In addition, the average standard of life for all the population would increase, because they would also be better inserted into the economy, working and opening business, helping the whole economy to move forward and to develop. However, if the law confusion remains, huge taxes are imposed, corruption flourishes, and massive bureaucracy grows, Brazil is going to remain a poor country exporting raw materials and keeping its colonial tradition possibly for the next 500 years.

\section{Acknowledgements}

Special acknowledgment and thanks to doc. Ing. Zuzana Pěničková, Ph.D. for her kind help with the research.

\section{References}

[1] CONSULADO GERAL DA REPÚBLICA TCHECA: Obchodní a ekonomická spolupráce s $\check{C} R$. [online]. 2008. [accessed 2017-01-30]. Available from WWW: www.mzV.cz

[2] MDIC (Brazilian Ministry of Industry, External Trade and Services): Brazilian Historical Commercial Trade with Czech Republic. [Microsoft Excel spreadsheet]. 2016. [accessed 2017-01-10]. Available from WWW: $\underline{\text { ww.mdic.gov.br }}$

[3] MDIC (Brazilian Ministry of Industry, External Trade and Services): Brazilian Historical Export and Import per category per country. [Microsoft Excel spreadsheet]. 2016. [accessed 2017-01-10]. Available from WWW: www.mdic.gov.br 
[4] MDIC (Brazilian Ministry of Industry, External Trade and Services): Brazilian Historical Export and Import per Product per country. [Microsoft Excel spreadsheet]. 2016. [accessed 2017-01-10]. Available from WWW: www.mdic.gov.br

[5] WORLD BANK GROUP: Brazil. [online]. 2017. [accessed 2017-01-28]. Available from WWW: www.doingbusiness.org

[6] WORLD BANK GROUP: Germany. [online]. 2017. [accessed 2017-01-28]. Available from WWW: www.doingbusiness.org

[7] WORLD BANK GROUP: Czech Republic. [online]. 2017. [accessed 2017-01-30]. Available from WWW: www.doingbusiness.org

[8] EUROPEAN COMMISSION: Trade Barriers Brazil. [online]. 2017. [accessed 201701-30]. Available from WWW: www.madb.europa.eu

[9] JURIDICAL COUNSIL: Veja como ficará o perfil da Câmara dos Deputados a partir de 2015. [online]. 2014. [accessed 2017-01-30]. Available from WWW: www.conjur.com.br

[10] G1: Quanto pagamos de impostos. [online]. 2014. [accessed 2017-01-30]. Available from WWW: www.g1.com.br

[11] BRAZILIAN GOVERNMENT: Tabela IPI. [online]. 2016. [accessed 2017-01-10]. Available from WWW: www.planalto.gov.br

[12] EPOCA NEGÓCIOS: Trabalhadores informais chegam a 10 milhões no Brasil. [online]. 2016. [accessed 2017-01-30]. Available from WWW: www.epocanegocios.com.br

[13] EXAME: Os 16 maiores problemas para se fazerem negócios no Brasil. [online]. 2016. [accessed 2017-01-30]. Available from WWW: www.exame.com.br

[14] BRAZILIAN GOVERNMENT: Employment costs are beyond salaries. [online]. 2012. [accessed 2017-01-10]. Available from WWW: www.brasil.gov.br

[15] BRAZILIAN GOVERNMENT: CLT: Consolidação das Leis. [online]. 1943. [accessed 2017-01-10]. Available from WWW: www.brasil.gov.br

[16] ESTADAO: Ações trabalhistas crescem e TST prevê 3 milhões de processos em 2016. [online]. 2016. [accessed 2017-02-10]. Available from WWW: www.estadao.com.br

[17] GLOBO: Com mais de 250 novos sindicatos por ano, Brasil já tem mais de 15 mil entidades. [online]. 2016. [accessed 2017-02-10]. Available from WWW: www.oglobo.com.br

[18] INTERNATIONAL TRANSPARENCY: Rankings. [online]. 2016. [accessed 2017-0110]. Available from WWW: www.transparency.org

[19] JUSBRASIL: Trafico de Influencia. [online]. 2016. [accessed 2017-01-10]. Available from WWW: www.jusbrasil.com.br

[20] BBC: Escândalo da Petrobras 'engoliu 2.5\% da economia em 2015. [online]. 2016. [accessed 2017-01-10]. Available at: www.bbc.com

[21] BCB (BRAZILIAN CENTRAL BANK): Home Page. [online]. 2017. [accessed 201701-10]. Available from WWW: www.bcb.gov.br

[22] FED (U.S.A. FEDERAL RESERVE): Interest Rates. [online]. 2017. [accessed 201701-10]. Available from WWW: www.federalreserve.gov 
[23] BRITISH COUNCIL: English Proficiency in Brazil. [online]. 2014. [accessed 2017-0110]. Available from WWW: www.BritishCouncil.com

[24] PRNEWSWIRE: Faber-castell-comemora-85-anos-no-brasil. [online]. 2015. [accessed 2017-01-10]. Available from WWW: www.prnewswire.com

[25] BNDES (BRAZILIAN NATIONAL BANK FOR ECONOMIC DEVELOPMENT): Critérios e instruções para cálculo de índices de nacionalização. [online]. 2007. [accessed 2017-01-10]. Available from WWW: www.bndes.gov.br

[26] UOL: Burocracia dificulta importar carro, mas preço final pode compensar. [online]. 2014. [accessed 2017-01-30]. Available from WWW: www.uol.com.br

[27] EXAME: Montadoras chinesas vieram para vencer - mas deu tudo errado. [online]. 2014. [accessed 2017-02-15]. Available from WWW: $\underline{\text { www.exame.com.br }}$

[28] RF (CUSTOMS AGENCY): Importação. [online]. 2014. [accessed 2017-02-15]. Available from WWW: $\underline{w w w . i d g . r e c e i t a . f a z e n d o . g o v . b r}$

[29] WORLD BANK THROUGH GOOGLE PUBLIC DATA: FDI - Paraguay. [online]. 2016. [accessed 2017-02-15]. Available from WWW: www.google.cz/publicdata/

[30] ICP (INDUSTRIAL CHAMBER OF PARAGUAY): Que es Maquila? [online]. 2015. [accessed 2017-02-15]. Available from WWW: www.maquila.org.py

[31] PARAGUAY GOVERNMENT: LEY No 1.064/97. [online]. 1997. [accessed 2017-0215]. Available from WWW: www.aduana.gov.py

[32] WORLD BANK GROUP: Paraguay. [online]. 2017. [accessed 2017-01-28]. Available from WWW: www.doingbusiness.org

[33] SISCOMEX: Tarifa Externa Comum. [online]. 2015. [accessed 2017-01-28]. Available from WWW: www.portalsiscomex.gov.br

[34] VEJA: Mais de 3 milhões de ações chegam à Justiça do Trabalho em 2016. [online]. 2016. [accessed 2017-01-28]. Available from WWW: www.veja.com.br

[35] OSWALDO CRUZ FOUNDATION: Importação - passo a passo. [online]. 2016. [accessed 2017-01-28]. Available from WWW: $\underline{\text { www.dirad.fiocruz.br }}$

[36] RF (CUSTOMS AGENCY): Manual de Importação. [online]. 2015. [accessed 201702-15]. Available from WWW: www.idg.receita.fazendo.gov.br

[37] BCB (BRAZILIAN CENTRAL BANK): Envio e recebimento de recursos em moeda estrangeira. [online]. 2014. [accessed 2017-01-10]. Available from WWW: www.bcb.gov.br

[38] SISCOMEX: Bens sujeitos a licença ou proibição na importação. [online]. 2015. [accessed 2017-01-28]. Available from WWW: www.portalsiscomex.gov.br

[39] SISCOMEX SYSTEM: Bens sujeitos a licença ou proibição na importação. [online]. 2015. [accessed 2017-01-30]. Available from WWW: www.portalsiscomex.gov.br

[40] KUADA, J.: Internationalization of Companies from developing Countries. Routledge, New York, 2000. ISBN 0-7890-0721-5.

[41] ELLIS, J.: International Bussiness Strategy. Financial Times Management, London, 1995. ISBN 027360712X.

[42] BRAINARD, L.: Brazil as an economical superpower. The brooking institution, Washington, 2009. ISBN 978-0-8157-0295-5. 
[43] MDIC (BRAZILIAN MINISTRY OF INDUSTRY, EXTERNAL TRADE AND SERVICES): Brazilian Import per Aggregated Factor. [Microsoft Excel spreadsheet]. [online] 2016. [accessed 2017-01-10]. Available from WWW: www.mdic.gov.br

[44] OECD STATISTICS: Population and Labor Force in Brazil. [online]. 2017. [accessed 2017-01-20]. Available from WWW: stats.oecd.org

[45] CONSULADO GERAL DA REPÚBLICA TCHECA: Reunião com empresas tchecas. [online]. 2016. [accessed 2017-01-20]. Available from WWW: www.mzv.cz

[46] MINISTÉRIO PUBLICO FEDERAL: Lava Jato em numeros. [online]. 2017. [accessed 2017-01-20]. Available from WWW: www.lavajato.mpf.mp.br

[47] AMCHAM: Mudanças na tributação. [online]. 2017. [accessed 2017-01-20]. Available from WWW: www.amcham.com.br

[48] CZECH MINISTRY OF INDUSTRY AND TRADE: Report on implementation of the Export Strategy of the Czech Republic 2012-2020. [online]. 2013. [accessed 2017-0120]. Available from WWW: www.mpo.cz

Renan Stefanutti 


\section{INTERNACIONALIZACE ČESKÝCH FIREM V BRAZÍLII}

Článek v první části přináší přehled česko-brazilského bilaterálního obchodu a jeho změn v průběhu let, představuje nejdůležitější komodity exportu a importu.

Druhá část se věnuje možnostem podnikání na největším trhu Latinské Ameriky, jsou rozebrány překážky v podnikání, uvedeny názorné př́iklady a je nabídnuto srovnání se situací v České republice a Německu. Jsou zde také analyzována ochranná opatření, popsána idea protekcionismu a současný vliv na dovoz zboží ze zahraničí.

$\mathrm{V}$ třetí části autor analyzuje možné způsoby, jak v Brazílii úspěšně podnikat, a vysvětluje na př́kladech již zavedených firem, jak legálně operovat v tomto podnikatelském prostředí.

\section{INTERNATIONALISIERUNG TSCHECHISCHER FIRMEN IN BRASILIEN}

Dieser Artikel bietet einen Überblick über den tschechisch-brasilianischen bilateralen Handel und dessen im Laufe der Zeit eingetretenen Änderungen und stellt die wichtigsten Waren für den In- und Export vor.

Der zweite Teil widmet sich den Unternehmensmöglichkeiten auf dem größten Markt Lateinamerikas. Es werden Hindernisfaktoren analysiert und anschauliche Beispiele angeführt. Des Weiteren werden die dortige Situation und die Situation in der Tschechischen Republik und in Deutschland miteinander verglichen. Auch die Schutzmaßnahmen werden hier analysiert und die Idee des Protektionismus und der gegenwärtige Einfluss auf den Import von Waren aus dem Ausland beschrieben.

Im dritten Teil analysiert der Autor mögliche Arten und Weisen, wie man in Brasilien erfolgreich unternehmen kann, und erklärt an den Beispiel bereit eingeführter Firmen, wie man legal in diesem unternehmerischen Umfeld operieren kann.

\section{INTERNACJONALIZACJA CZESKICH FIRM W BRAZYLII}

W pierwszej części artykułu przedstawiono informacje dotyczące czesko-brazylijskiej wymiany handlowej i jej zmian na przestrzeni lat a także zaprezentowano najważniejsze produkty będące przedmiotem eksportu i importu.

W drugiej części uwagę poświęcono możliwościom prowadzenia działalności gospodarczej na największym rynku Ameryki Łacińskiej, omówiono bariery w jej prowadzeniu, pokazano przykłady i dokonano porównania z sytuacją w Republice Czeskiej i Niemczech. Ponadto analizie poddano działania ochronne, opisano ideę protekcjonizmu i obecny wpływ na import towarów z zagranicy.

W trzeciej części autor analizuje możliwe sposoby udanego prowadzenia działalności gospodarczej w Brazylii i na przykładach już istniejących firm wyjaśnia, w jaki sposób legalnie poruszać się w tym środowisku biznesowym. 